\title{
Peran Badan Usaha Milik Desa (BUM-Des) dalam Meningkatkan Pendapatan Usaha Kecil Menengah (UKM) di Desa Gerung Permai, Kecamatan Suralaga, Kabupaten Lombok Timur
}

\author{
Salmi Yuniar Bahri ${ }^{1}$, Abdul Khalik ${ }^{2}$, Martin Romiza ${ }^{3}$ \\ ${ }^{1,2,3}$ STIA Muhammadiyah Selong
}

\begin{tabular}{l}
\hline Article Info \\
\hline Article history: \\
Received 08 Desember 2021 \\
Publish 02 Januari 2022 \\
\\
\hline Keywords: \\
BUMDes \\
Income \\
Role \\
Small and Medium Enterprises.
\end{tabular}

Info Artikel

Article history:

Diterima 08 Desember 2021

Publis 02 Januari 2022

\begin{abstract}
Small and Medium Enterprises (SMEs) are one of the pillars of the domestic economy, especially for village government. However, they often do not get good support from the village government. Therefore, the government must involve the existence of Village-Owned Enterprises (BUMDes) to increase the income of SMEs so that they can improve the village economy. Village-Owned Enterprises have become a pillar of social economy (social economy) and commercial (commercial Institution) for people who want to manage and develop the potential and needs of villages to be used as business facilities in increasing village community income, as well as contributing to good social service and presentation. Meanwhile, as a commercial institution, it aims to seek profit through offering local resources (goods and services) to the community. This research uses a qualitative descriptive approach that emphasizes understanding the design of the proposed social phenomenon approach from the subject of the research perspective. This research was conducted in Gerung Permai Village, Suralaga District, East Lombok Regency by involving BUMDes Management and UKM actors as sources of data taken by means of interviews and questionnaires. The results of the research are that BUMDes Gerung Permai, Suralaga District, East Lombok Regency supports the existence of SMEs as a means to improve the community's economy. Therefore, BUMDes plays an active role in providing assistance to SMEs in the form of savings and loans with only one percent interest.

\begin{tabular}{l}
\hline Abstrak \\
Usaha Kecil Menengah (UKM) merupakan salah satu pilar perekonomian di dalam \\
negeri, terlebih bagi pemerintahan tingkat desa. Namun keberadaannya seringkali \\
tidak mendapatkan dukungan yang baik dari pemerintah desa. Karena itu, \\
pemerintah harusnya melibatkan keberadaan Badan Usaha Milik Desa (BUMDes) \\
untuk meningkatkan pendapatan pelaku UKM sehingga dapat berkontribusi pada \\
perekonomian desa. Badan Usaha Milik Desa telah menjadi pilar prekonomian \\
sosial (social ecomic) dan komersial (comersial institution) bagi masayarakat yang \\
ingin mengelola dan mengembangkan potensi dan kebutuhan desa untuk dijadikan \\
sarana usaha dalam meningkatkan pendapatan masyarakat desa, serta kontribusinya \\
dalam penyajian dan pelayanan sosial yang baik. Sedangkan sebagai lembaga \\
komersial bertujuan mencari keuntungan melalui penawaran sumber daya lokal \\
(barang dan jasa) ke masyarakat. Rancangan penelitian ini menggunakan jenis dan \\
pendekatan deskriftif Kualitatif yang ditekankan pada pemahaman terhadap \\
pendekatan fenomena sosial ditinjau dari prespektif subjek penelitian. Penelitian ini \\
dilakukan di Desa Gerung Permai Kecamatan Suralaga Kabupaten Lombok Timur \\
dengan melibatkan Pengurus BUMDes dan Pelaku UKM sebagai sumber data yang \\
diambil dengan cara wawancara dan kuisioner. Hasil dari penelitian adalah bahwa \\
BUMDes Gerung Permai Kecamatan Suralaga Kabupaten Lombok Timur \\
mendukung keberadaan UKM sebagai salah satu sarana untuk Meningkatkan \\
perekonomian masyarakat. Oleh karena itu, BUMDes berperan aktif dalam \\
memberikan bantuan kepada Pelaku UKM dalam bentuk simpan pinjam dengan \\
bunga pengembalian hanya satu persen.
\end{tabular}
\end{abstract}

This is an open access article under the Lisensi Creative Commons Atribusi- 
Corresponding Author:

Salmi Yuniar Bahri,

STIA Muhammadiyah Selong

Email: salmijuniar@gmail.com

\section{PENDAhULUAN}

Indonesia sebagai negara berkembang terus menerus meningkatkan pembangunan diberbagai sektor, mulai dari sektor perekonomian, sektor pembangunan daerah terpencil dan sektor pendidikan. Amanat Pancasila dan Undang-Undang Dasar (UUD) 1945 tentang keadilan sosial bagi seluruh rakyat Indonesia diperjelas dengan disahkannya Undang-Undang Nomor 6 Tahun 2014 tentang desa dalam sidang paripurna Dewan Perwakilan Rakyat Republik Indonesia (DPR-RI) yang berisi tentang Penyelenggaraan Pemerintahan Desa, pelaksanaan Pembangunan Desa, pembinaan kemasyarakatan Desa, dan pemberdayaan masyarakat Desa. Undang-undang ini menjadi kemenangan besar bagi bangsa, sebab Undang-Undang ini menjadi bukti ketegasan dan komitmen pemerintah untuk melindungi dan memberdayakan sumber daya desa agar menjadi lebih kuat, mandiri dan demokratis sehinga dapat menciptakan landasan yang kokoh dalam melaksanakan pemerintahan dan pembangunan menuju masyarakat yang adil, makmur, dan sejahtera. Dengan mengacu pada Undang-Undang tersebut, maka ada harapan baru bagi bangsa dan masyarakat dalam memperbaiki nasib prekonomiannya melalui Badan Usaha Milik Desa yang disebut BUMDes ini menjadi inovasi penting dan layak diapresiasi ditengah kondisi dan dalam waktu yang lama desa selalu ditinggalkan (Sahdan, 2005).

Badan Usaha Milik Desa telah menjadi pilar prekonomian sosial (social ecomic) dan komersial (comersial institution) bagi masayarakat yang ingin mengelola dan mengembangkan potensi dan kebutuhan desa untuk dijadikan sarana usaha dalam meningkatkan pendapatan masyarakat desa, serta kontribusinya dalam penyajian dan pelayanan sosial yang baik. Sedangkan sebagai lembaga komersial bertujuan mencari keuntungan melalui penawaran sumber daya lokal (barang dan jasa) ke masyarakat. Keberadaan BUMDes ini diatur dalam UU No. 32 Tahun 2004 pasal 213 ayat (1) yang menegaskan bahwa Desa dapat mendirikan Badan Usaha Milik Desa sesuai dengan kebutuhan dan potensi desa. Selain itu juga diatur dalam Peraturan Pemerintah Nomor 72 Tahun 2005 pasal 78-81 dan Permendagri Nomor 39 Tahun 2010 mengatur tentang Badan Usaha Milik Desa. Keberadaan BUMDes diatur dalam Permendagri nomor 39 tahun 2010 berfungsi sebagai mobilitas perekonomian desa, terutama dalam meningkat pendapatan masyarakat desa yang mengelola kegiatan usaha. Hal ini menjadi harapan baru bagi masyarakat desa untuk memanfaatkan potensi desa baik sumber daya alam dan sumber daya manusianya terhadap kebutuhan masyarakat desa. Sehinggaakan terjadi peningkatan kesempatan berusaha dalam rangka memperkuat ekonomi desa dan mengurangi angka pengangguran (Dewi \& Prasetyo, 2015).

Badan Usaha Milik Desa merupakan suatu lembaga yang dimiliki oleh pemerintah desa yang bergerak dibidang prekonomian sebagai wujud serta kiprah pemerintah kepada masyarakat desa untuk terus mengembangkan dan menggali potensi desa dan kebutuhan masyarakat desa serta mekanisme pengelolaannya dapat dilakukan oleh masyarakat dan pemerintah desa. Adanya BUMDes ini telah menjadi wadah bagi pelaku usaha kecil menengah (UKM) untuk mengembangkan usahanya. Kerjasama yang baik antara BUMDes dengan UKM harus diberikan apresiasi yang tinggi. Selama ini UKM jarang diperhatikan oleh desa secara finansial meskipun pelaku UKM telah memberikan dampak pendapatan terhadap masyarakat desa. UKM ini menjadi bagian penting bagi desa untuk terus diberikan peluang dalam mengembangkan potensi masyarakat desa. Pemerintah desa dan Badan Usaha Milik Desa harus memberikan pemahaman yang lebih baik 
kepada masyarakat untuk pentingnya kegiatan usaha dalam menopang prekonomian atau tingkat pendapatan masyarakat desa (Arsyad, 2015).

Penelitian ini bertujuan untuk mengetahui sejauh mana peran BUMDes dalam memajukan perekonomian di desa. Peran BUMDes sebagai lembaga resmi desa dalam memberikan bantuan kepada Pelaku UKM dalam meningkatkan pendapatannya. Selain itu, Penelitian ini bertujuan untuk mengetahui faktor pendukung dan penghambat BUMDes dalam meningkatkan pendapatan UKM di Desa Gerung Permai Kecamatan Suralaga Kabupaten Lombok Timur.

\section{KAJIAN PUSTAKA}

\section{Peran}

Indonesia sebagai negara berkembang terus menerus meningkatkan pembangunan diberbagai sektor, mulai dari sektor perekonomian, sektor pembangunan daerah terpencil dan sektor pendidikan. Amanat Pancasila dan Undang-Undang Dasar (UUD) 1945 tentang keadilan sosial bagi seluruh rakyat Indonesia diperjelas dengan disahkannya Undang-Undang Nomor 6 Tahun 2014 tentang desa dalam sidang paripurna Dewan Perwakilan Rakyat Republik Indonesia (DPR-RI) yang berisi tentang Penyelenggaraan Pemerintahan Desa, pelaksanaan Pembangunan Desa, pembinaan kemasyarakatan Desa, dan pemberdayaan masyarakat Desa. Undang-undang ini menjadi kemenangan besar bagi bangsa, sebab Undang-Undang ini menjadi bukti ketegasan dan komitmen pemerintah untuk melindungi dan memberdayakan sumber daya desa agar menjadi lebih kuat, mandiri dan demokratis sehinga dapat menciptakan landasan yang kokoh dalam melaksanakan pemerintahan dan pembangunan menuju masyarakat yang adil, makmur, dan sejahtera. Dengan mengacu pada Undang-Undang tersebut, maka ada harapan baru bagi bangsa dan masyarakat dalam memperbaiki nasib prekonomiannya melalui Badan Usaha Milik Desa yang disebut BUMDes ini menjadi inovasi penting dan layak diapresiasi ditengah kondisi dan dalam waktu yang lama desa selalu ditinggalkan (Sahdan, 2005).

Badan Usaha Milik Desa telah menjadi pilar prekonomian sosial (social ecomic) dan komersial (comersial institution) bagi masayarakat yang ingin mengelola dan mengembangkan potensi dan kebutuhan desa untuk dijadikan sarana usaha dalam meningkatkan pendapatan masyarakat desa, serta kontribusinya dalam penyajian dan pelayanan sosial yang baik. Sedangkan sebagai lembaga komersial bertujuan mencari keuntungan melalui penawaran sumber daya lokal (barang dan jasa) ke masyarakat. Keberadaan BUMDes ini diatur dalam UU No. 32 Tahun 2004 pasal 213 ayat (1) yang menegaskan bahwa Desa dapat mendirikan Badan Usaha Milik Desa sesuai dengan kebutuhan dan potensi desa. Selain itu juga diatur dalam Peraturan Pemerintah Nomor 72 Tahun 2005 pasal 78-81 dan Permendagri Nomor 39 Tahun 2010 mengatur tentang Badan Usaha Milik Desa. Keberadaan BUMDes diatur dalam Permendagri nomor 39 tahun 2010 berfungsi sebagai mobilitas perekonomian desa, terutama dalam meningkat pendapatan masyarakat desa yang mengelola kegiatan usaha. Hal ini menjadi harapan baru bagi masyarakat desa untuk memanfaatkan potensi desa baik sumber daya alam dan sumber daya manusianya terhadap kebutuhan masyarakat desa. Sehinggaakan terjadi peningkatan kesempatan berusaha dalam rangka memperkuat ekonomi desa dan mengurangi angka pengangguran (Dewi \& Prasetyo, 2015).

Badan Usaha Milik Desa merupakan suatu lembaga yang dimiliki oleh pemerintah desa yang bergerak dibidang prekonomian sebagai wujud serta kiprah pemerintah kepada masyarakat desa untuk terus mengembangkan dan menggali potensi desa dan kebutuhan masyarakat desa serta mekanisme pengelolaannya dapat dilakukan oleh masyarakat dan pemerintah desa. Adanya BUMDes ini telah menjadi wadah bagi pelaku usaha kecil menengah (UKM) untuk mengembangkan usahanya. Kerjasama yang baik antara BUMDes dengan UKM harus diberikan apresiasi yang tinggi. Selama ini UKM jarang diperhatikan oleh desa secara finansial meskipun pelaku UKM telah memberikan dampak pendapatan terhadap masyarakat desa. UKM ini menjadi bagian penting bagi desa untuk terus diberikan peluang dalam mengembangkan potensi masyarakat 
desa. Pemerintah desa dan Badan Usaha Milik Desa harus memberikan pemahaman yang lebih baik kepada masyarakat untuk pentingnya kegiatan usaha dalam menopang prekonomian atau tingkat pendapatan masyarakat desa (Arsyad, 2015).

Penelitian ini bertujuan untuk mengetahui sejauh mana peran BUMDes dalam memajukan perekonomian di desa. Peran BUMDes sebagai lembaga resmi desa dalam memberikan bantuan kepada Pelaku UKM dalam meningkatkan pendapatannya. Selain itu, Penelitian ini bertujuan untuk mengetahui faktor pendukung dan penghambat BUMDes dalam meningkatkan pendapatan UKM di Desa Gerung Permai Kecamatan Suralaga Kabupaten Lombok Timur.

\section{Badan Usaha Milik Desa (BUMDes)}

Permendagri No. 39 Tahun 2010, mendefinisikan BUMDes sebagai usaha desa yang dibentuk atau didirikan oleh pemerintah desa yang kepemilikan modal dan pengelolaannya dilakukan oleh pemerintah desa dan masyarakat. Selanjutnya, sistem pengelolaannya dilaksakan oleh masyarakat dan pemerintah desa dalam upaya memperkuat perekonomian desa. BUMDes juga diartikan sebagai lembaga usaha yang bergerak dalam bidang pengelolaan aset-aset dan sumberdaya ekonomi dalam meningkatkan dan memberdayakan masyarakat desa. Definisi tersebut patut disematkan pada BUMDes sebagaimana dalam UU Desa yaitu badan usaha yang seluruhnya atau sebagian besar modalnya dimiliki oleh desa melalui penyertaan secara langsung yang berasal dari potensi atau kekayaan desa baik dalam pengelolaan aset, jasa, pelayanan dan usaha lainnya untuk dapat dimanfaatkan secara langsung oleh masyarakat desa demi menunjang kesetabilan prekonomian masyarakat (Zulkarnain, 2015).

Tujuan didirikannya BUMDes menurut Purnomo (2004) adalah : (a) untuk meningkatkan peranan masyarakat desa dalam mengelola sumber-sumber pendapatan lain yang sah, (b) menumbuh kembangkan usaha disektor informal untuk dapat menyerap tenaga kerja masyarakat di desa, (c) menumbuh kembangkan kegiatan ekonomi masyarakat desa dalam unit-unit usaha desa secara kecil-kecilan, (d) meningkatkan kreatifitas berwirausaha masyarakat yang sistem pengelolaan permodalannya dibantu oleh BUMDes, dan (e) memberdayakan masyarakat dengan membuat lapangan kerja baru bagi masyarakat desa yang masih menganggur. Karena pentingnya peran BUMDes dalam memajukan perekonomian desa, BUMDes diatur dalam UU No. 32 Tahun 2004 tentang Pemerintah Daerah, PP No.72 Tahun 2005 tentang desa, serta diperkuat dengan UU No. 6 Tahun 2014 pada pasal 87 ayat 3 yang mengatur tentang tata cara pendirian dan regulasi yang harus dijalankan oleh BUMDes dalam Meningkatkan kesejahteraan masyarakat desa.

\section{Usaha Kecil Menengah (UKM)}

Usaha kecil menengah adalah salah satu bagian penting dari prekonomian suatu Negara maupun daerah yang dapat meningkatkan kinerja dari setiap orang baik secara ekonomi produktif, inovatif dan kreatif. Usaha kecil menengah ini sangat berpengaruh terhadap lajunya prekonomian masyarakat desa. Selain itu UKM juga sangat membantu negara dan daerah serta pemerintah dalam hal penciptaan lapangan kerja baru bagi masyarakat yang membutuhkan pekerjaan, dengan adanya UKM banyak tercipta unit-unit kerja baru yang menggunakan tenaga-tenaga baru yang dapat mendukung pendapatan rumah tangga (Tambunan, 2009).

Adapun krakteristik UKM adalah sebagai berikut: (a) sistem pembukaan sangat sederhana dan cenderung tidak mengikuti kaidah administrasi pembukaan yang standar, (b) margin usaha yang cenderung tipis mengingat persaingan yang sangat tinggi, (c) modal yang terbatas, (d) pengalaman manejerial dalam pengelolaan masih sangat terbatas, (e) skala ekonomi yang terlalu kecil, sehingga sulit untuk mengaharapkan, untuk mampu menekan biaya mencapai titik efesiensi jangka panjang, (f) kemampuan pemasaran dan negosisasi pada pasar sangat terbatas, dan (g) kemampuan untuk memperoleh sumber dana dari pasar modal rendah, mengingat keterbatasan dalam sistem administrasinya (Anoraga, 2007). 


\section{Peran BUMDes dalam Meningkatkan Pendapatan UKM}

BUMDes sebagai lembaga usaha pemerintah desa sudah sangat diakui perannya dalam meningkatkan prekonomian masyarakat dan desa, sebab lembaga usaha ini memberikan kewenangan penuh kepada masyarakat agar ikut serta dalam mengelola usaha yang dilakukan oleh BUMDes. Manfaat dari usaha yang dilakukan itu dapat dirasakan secara langsung oleh masyarakat yang mengelola dan melaksanakan serta menjalankan sistem usaha yang dibuat oleh BUMDes.

Menurut Seyadi (2003) BUMDes berperan penting dalam pemberdayaan perekonomian masyarakat. Terdapat beberapa peran BUMDes dalam pemberdayaan ekonomi masyarakat yaitu: (a) pembangunan dan pengembangan potensi dan kemampuan ekonomi masyarakat desa pada umumnya untuk meningakatkan kesejahteraan ekonomi dan sosialnya, (b) berperan secara aktif dalam upaya mempertinggi kualitas kehidupan manusia dan masyarakat, (c) memperkokoh perekonomian rakyat sebagai dasar kekuatan dan ketahanan perekonomian Nasional dengan BUMDes sebagai pondasinya, (d) berusaha untuk mewujudkan dan mengembangkan perekonomian masyarakat desa, dan (e) membantu masyarakat untuk meningkatkan pendapatan mereka secara langsung oleh hasil usaha yang dikelolanya.

\section{METODE PENELITIAN}

Rancangan penelitian ini menggunakan jenis dan pendekatan deskriftif kualitatif. Pada penelitian ini lebih ditekankan pada pemahaman terhadap pendekatan fenomena sosial ditinjau dari prespektif subjek penelitian. Deskriptif kualitatif digunakan dalam penelitian ini karena pendekatan ini memfokuskan perhatiannya kepada prinsip-prinsip umum yang mendasari perwujudan satuansatuan gejala yang ada dalam kehidupan manusia, atau pola-pola yang dianalisis gejala-gejala sosial budaya dengan menggunakan kebudayaan dari masyarakat yang bersangkutan untuk memperoleh gambaran mengenai polapola yang berlaku.

Penelitian ini dilakukan di Desa Gerung Permai Kecamatan Suralaga Kabupaten Lombok Timur dengan fokus penelitian terfokus pada peran penting yang dimiliki oleh BUMDes dalam meningkatkan pendapatan UKM. Adapun data didapatkan melalui teknik wawancara secara langsung dengan pengurus BUMDes setempat dan Pengurus UKM yang mendapatkan dana bantuan dari dana desa yang dikelola oleh BUMDes tersebut sebagai data primer. Selain itu, untuk melengkapi data dalam penelitian ini, dilakukan observasi lapangan, dan mendokumentasikan setiap arsip, surat atau berupa photo kegiatan UKM dan BUMDes yang diperlukan dalam penelitian serta dokumen-dokumen yag berhubungan dengan data penelitian ini yang dipusatkan pada peran BUMDes di Desa Gerung Permai Kecamatan Suralaga Kabupaten Lombok Timur secara terlampir serta peraturan perundang-undangan yang mengatur tentang BUMDes dan UKM ini sebagai data sekunder.

\section{HASIL PENELITIAN DAN PEMBAHASAN}

Mengingat bahwa jenis data yang digunakan dalam penelitian ini adalah pendekatan kualitatif, maka data yang diproleh berbentuk kata atau kalimat dari hasil wawancara, observasi serta data atau hasil dokumentasi lainnya. Dalam penelitian ini kata-kata dan tindakan orang yang diwawancarai merupakan sumber utama dalam penelitian ini. Sumber data ini kemudian oleh peneliti dicatat dengan menggunakan catatan tertulis. Bedasarkan teknik analisa data kualitatif, data-data tersebut dianalisa selama penelitian berlangsung. Data yang diproleh dari hasil wawancara, observasi lapangan dan kajian pustaka kemudian dilakukan kebentuk tertulis untuk mendapatkan hasil yang kebih valid. Adapun data yang berhasil dikumpulkan dikelola menjadi sebuah kalimat yang merupakan hasil dari penelitian ini.

Hasil wawancara dengan Ridwan (2020) menyatakan bahwa BUMDes baru dikenal oleh masyarakat desa pada tahun 2018 meski BUMDes di Desa Gerung Permai dibentuk pada tahun 2016, namun masih banyak yang diperlukan dalam mengelolanya seperti adanya Perdes yang 
merujuk kepada Perbub yang dibuat oleh pemerintah terkait. Sebab BUMDes didirikan untuk menambah ksejahteraan masyarakat desa bukan merugikan desa maupun masyarakat yang mengelolanya terutama dalam melakukan kegiatan usaha, sehingga semua peraturan harus mengacu pada peraturan tertinggi, mulai dari undang-undang, peraturan gubernur dan peraturan bupati sebagai acuan dalam membuat perdes tentang BUMDes (Qadriadi, 2020).

Amrullah (2020) melanjutkan bahwa BUMDes Gerung Permai memberikan kemudahan bagi masyarakat yang ingin mengembangkan usahanya, terlebih bagi UKM yang baru memulai kegiatan usahanya seperti adanya persiapan modal usaha yang diberikan kepada masyarakat, dengan ketentuan dan perjanjian yang berlaku. BUMDes Gerung Pemai tidak mempersulit masyarakat yang ingin menggunakan modal usahanya, masyarakat yang ingin melakukan kegiatan usaha dan tidak cukup modal maka BUMDes Gerung Permai mengatasi hal tersebut dengan memberikan modal usaha hanya dengan syarat membawa Kartu Tanda Penduduk (KTP) dan Kartu Keluarga (KK). BUMDes Gerung Permai memiliki peran aktif dalam mempersiapkan modal usaha secara mudah dan gampang tanpa berbelit-belit dalam bentuk simpan pinjam.Adapunjumlah pinjaman yang diberikan kepada masyarakat tergantung dari modal usaha yang mereka butuhkan selama modal yang ada di BUMDes masih mampu mengatasinya. BUMDes Gerung Permai hanya menarik 1 persen bunga pinjaman yang diberikan kepada para Pelaku UKM yang meminjam modal untuk mengembangkan usahanya (Intan, 2020).

Berdasarkan UU No. 6 Tahun 2014 tentang kemandirian desa dalam membangun wilayahnya, pemerintah desa berhak membentuk suatu lembaga usaha seperti Badan Usaha Milik Desa atau yang kita kenal dengan nama BUMDes. Upaya-upaya ini Kementerian Desa memberikan hak kepada pemerintah desa agar terus berinovasi dan berkreasi untuk memajukan masyarakat desa dalam berbagai sektor khususnya disektor usaha. Memang sektor usaha menjadi bagian penting dalam memajukan tingkat pendapatan prekonomian rakyat. keberadaan BUMDes telah menjadi momentum berharga bagi masyarakat untuk mengubah nasib dalam kehidupannya, hal ini dikarenakan BUMDes memberikan kesempatan bagi masyarakat yang ingin mengembangkan atau membuka kegiatan usaha kecilkecilan atau dikatakan sebagai home industry, sehingga muncullah bibit-bibit baru dalam kegaiatan usaha seperti telah terbentuknya UKM Mele Maju dan UKM Taylor Siti (Ridwan, 2020).

Sampai dengan saat ini, terdapat dua UKM yang menjadi binaan dari BUMDes Gerung Permai, yaitu UKM Mele Maju dan UKM Tayor Siti. Dari hasil wawancara dengan kedua pimpinan UKM tersebut, dapat ditarik kesimpulan bahwa keberadaan BUMDes Gerung Permai yang memberikan bantuan berupa simpan pinjam kepada masyarakat yang berani menyaingi keberadaan bank konvensional telah mampu mengangkat perekonomian masyarakat setempat. peran BUMDes dalam meningkatkan pendapatan Usaha Kecil Menengah sangat-sangat signifikan, karena posisi BUMDes disini dijadikan sebagai pemodal yang tingkat persentase pengembalian dana yang tidak tinggi kepada masyarakat, sehingga masyarakat dapat mengelola dengan baik, serta adanya evaluasi dan monitoring BUMDes secara berkala yang dilakukan kepada pihak UKM itu sendiri.

BUMDes sebagai lembaga usaha yang dimiliki oleh desa telah mampu mengangkat martabat dari setiap orang yang ingin melakukan kegiatan usaha. Secara starata sosial kehidupan ekonomi masyarakat akan terus meningkat bila tingkat pendpatan mereka dibidang usaha terus berkembang, dan akhirnya tingkat kemandirian masyarakat akan terus terpacu dengan adanya pendapatan mereka yang secara nyata, serta akan berkurangnya angka penggangguran ditingkat pedesaan tersebut, sebagaimana yang tertuang dalam pancasila dan amanat UUD 1945 pada alinea ke-5 yaitu keadilan sosial bagi seluruh rakyat Indonesia. BUMDes

Tabel.1 Perbandingan Pendapatan Usaha Kecil Menengah Sebelum dan Sesudah Adanya 


\begin{tabular}{|c|c|c|c|c|c|c|c|c|c|}
\hline \multirow{2}{*}{ No } & \multirow{2}{*}{$\begin{array}{l}\text { Nama } \\
\text { UKM }\end{array}$} & \multicolumn{4}{|c|}{$\begin{array}{c}\text { Indikator Pendapatan Sebelum } \\
\text { Adanya BUMDes }\end{array}$} & \multicolumn{4}{|c|}{$\begin{array}{c}\text { Indikator Pendapatan Sesudah } \\
\text { Adanya BUMDes }\end{array}$} \\
\hline & & $\begin{array}{l}\text { Modal } \\
\text { Usaha }\end{array}$ & Pegawai & $\begin{array}{l}\text { Jam } \\
\text { Kerja }\end{array}$ & $\begin{array}{l}\text { Pendap } \\
\text { atan }\end{array}$ & $\begin{array}{l}\text { Modal } \\
\text { Usaha }\end{array}$ & Pegawai & $\begin{array}{l}\text { Jam } \\
\text { Kerja }\end{array}$ & $\begin{array}{l}\text { Penda } \\
\text { patan }\end{array}$ \\
\hline 1 & $\begin{array}{l}\text { UKM } \\
\text { Mele } \\
\text { Maju }\end{array}$ & $3 \mathrm{jt}$ & 2 orang & 5 jam /hari & 2 jt /bulan & $10 \mathrm{jt}$ & 5-6 orang & $\begin{array}{l}\text { 10jam } \\
\text { /hari }\end{array}$ & $\begin{array}{l}5-7 \mathrm{jt} \\
\text { /bulan }\end{array}$ \\
\hline 2 & $\begin{array}{r}\text { UKM } \\
\text { Taylor } \\
\text { Siti } \\
\end{array}$ & $2 \mathrm{jt}$ & 1 orang & 3 jam /hari & $\begin{array}{l}1-1,5 \\
\mathrm{jt} / \mathrm{bulan}\end{array}$ & $8 \mathrm{jt}$ & 5-6 orang & $\begin{array}{l}8 \text { jam } \\
\text { /hari }\end{array}$ & $\begin{array}{l}4-5 \mathrm{jt} \\
\text { /bulan }\end{array}$ \\
\hline
\end{tabular}

Jelas bahwa tabel diatas memberikan gambaran atas peran aktif BUMDes yang begitu signifikan terhadap majunya prekonomian rakyat, sehingga BUMDes yang merupakan lembaga usaha yang dimiliki desa sangat diperlukan perannya terus menerus dalam menopang kehidupan ekonomi masyarakat.

BUMDes sebagai lembaga usaha desa telah mampu memberikan dukungan kepada masyarakat akan pentingnya untuk terus melakukan kegiatan usaha, karena sektor prekonomian desa menjadi lumbung prekonomian nasional. Ada beberapa faktor pendukung BUMDes dalam meningkatkan pendapatan UKM, Diantaranya adalah : SDM yang memadai untuk mengelola setiap administrasi keuangan yang ada di BUMDes Gerung Permai, BUMDes dengan dana yang didapatkan dari desa dapat sebagai lembaga pemodal di UKM. Namun, sebagai lembaga pemerintahan, BUMDes harus melakukan monitoring dan evaluasi secara berkala untuk memastikan setiap program pemberdayaan masyarakat berjalan dengan baik.

Selain faktor pendukung BUMDes dalam Meningkatkan pendapatan UKM di desa Gerung Permai Kecamatan Suralaga Kabupaten Lombok Timur, terdapat juga faktor penghambatnya, diantaranya adalah (a) kurangnya modal yang dimiliki oleh BUMDes desa Gerung Permai Kecamatan Suralaga, (b) kurangnya keterampilan dan kecakapan sumber daya manusia dalam kepenggurusan BUMDes, (c) manajemen kelembagaan yang masih berjalan dengan kurang baik seperti perencanaan dalam menjalankan usaha untuk memperoleh keuntungan dan manfaat dengan maksimal, dan (d) kurangnya pengetahuan masyarakat tentang BUMDes dan masih minimnya partisipasi masyarakat dalam memajukan unit usaha yang dikelola masyarakat.

\section{KESIMPULAN}

Peran BUMDes dalam meningkatkan Pendapatan UKM telah terealisasi dengan adanya beberapa unit usaha yang sudah berdiri, BUMDes dalam meningkatkan pendapatan UKM di Desa Gerung Permai Kecamatan Suralaga Kabupaten Lombok Timur terdiri dari 2 UKM binaan yaitu; UKM Mele Maju (bergerak dibidang pembuatan tahu dan tempe), UKM Taylor Siti (bergerak dibidang penjahit). BUMDes Gerung Permai memiliki peran aktif dalam membina kelompok usaha. Selain itu BUMDes juga berperan dalam pembangunan dan pengembangan potensi desa sebagai ajang usaha yang dilakukan pihak untuk memajukan desanya.

Adapun sebagai lembaga desa yang berperan aktif membantu UKM untuk modal usaha berupa uang simpan pinjam, ada beberapa faktor pendukung yang dapat di mendorong BUMDes dalam Meningkatkan pendapatan UKM, tersedianya SDM yang memadai, dan adanya dana dari desa yang dapat dikelola secara professional oleh pengurus untuk dapat mengembangkan keuangan desa. Selain itu, terdapat faktor penghambat seperti manajemen kelembagaan yang masih berjalan dengan kurang baik dan kurangnya pengetahuan masyarakat tentang BUMDes serta minimnya partisipasi masyarakat dalam memajukan unit usaha yang dikelola masyarakat. Pada akhirnya, diakui bahwa Penelitian ini sangat terbatas karena hanya mengambil satu desa sebagai objek Penelitian, dimasa depan diharapkan peneliti mengguanakan lebih banyak objek dan Metodologi penelitian campuran sehingga mendapatkan hasil yang signifikan dan lebih lengkap. 


\section{DAFTAR PUSTAKA}

Ahram, T., Sargolzaei, A., \& Sargolzae, S. (2017). Blockchain Technology Innovations. Technology \& Engineering Management Conference.

Anoraga, P. (2007). Pengantar Bisnis, Pengelolaan Bisnis dalam Era Globalisasi. Jakarta: Rineka Cipta.

Arsyad, L. (2015). Ekonomi Pembangunan. Yogyakarta: UPP STIM YKPN.

Dewi, A. S., \& Prasetyo, N. (2015). Interpretasi Bentuk Badan Usaha Milik Desa Menurut Undang-Undang Nomor 6 Tahun 2014 tentang Desa. Media Hukum, 242-257.

Purnomo. (2004). Pembangunan Bumdes dan Pemberdayaan Masyarakat Desa. Makalah PMD Lombok Timur.

Raho, . (2007). Teori sosiologi modern. Jakarta: Prestasi Pustaka.

Sahdan, G. (2005). Menanggulangi Kemiskinan Desa. Ekonomi Rakyat.

Seyadi. (2003). Bumdes Sebagai Alternatif Lembaga Keuangan Desa. Yogyakarta: UPP STM YKPN.

Soekanto, S. (2002). Sosiologi Suatu Pengantar. Jakarta: Rajawali Press.

Tambunan, T. T. (2009). UMKM di Indonesia. Bogor: Ghalia Indonesia.

Zulkarnain, R. (2015). Urgensi Badan Usaha Milik Desa (BUMDes) dalam Pembangunan Perekonomian Desa. Ilmu Hukum. 